\title{
Policy, politics and leadership in slum upgrading: A comparative analysis of Harare and Kampala
}

\author{
Davison Muchadenyika ${ }^{\mathrm{a}, *}$, Jeremy Waiswa ${ }^{\mathrm{b}, \mathrm{c}}$

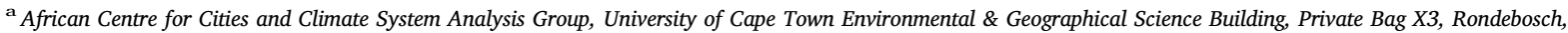 \\ 7701 Cape Town, South Africa \\ ${ }^{\mathrm{b}}$ Institute for Social Development, University of the Western Cape, Private Bag X17, Bellville, 7535 Cape Town, South Africa \\ ${ }^{\mathrm{c}}$ Uganda Christian University, P.O. Box 4, Mukono, Uganda
}

\section{A R T I C L E I N F O}

\section{Keywords:}

Policy

Leadership

Party-politics

Slum upgrading

Harare

Kampala

\begin{abstract}
A B S T R A C T
Slum upgrading is one of the preferred options in dealing with ubiquitous informality in cities across the world. Drawing on experiences in two African cities namely Harare and Kampala; the article focuses on the role of policy, politics and leadership in slum upgrading. This paper is based on interviews conducted with urban leaders and managers, politicians, slum dwellers federation members and government officials. With regards to slum upgrading, the paper makes three arguments. First, policies guiding upgrading should evolve gradually over time, taking into consideration lessons learned. Second, tensions in party-politics tend to undermine slum upgrading programmes. This is mainly because of the vulnerability of informal settlers who are often used as sources and resources for political agency. Third, leadership at the city level plays a fundamental role in diffusing party-politics and championing inclusive municipal governance, and development.
\end{abstract}

\section{Introduction}

One of the prominent challenges in African cities is the rapid increase in informal settlements and/or slums (Muchadenyika, 2015a). Slums are characterised by: limited access to safe drinking water and sanitation, insecure tenure, non-durable buildings and overcrowding (UN-Habitat, 2003). Slums encompass a wide range of informal settlements-like squatter settlements that currently epitomize urban poverty in global South cities (Ibid). Therefore, the term slum and informal settlement are in this paper used interchangeably. The absence of basic infrastructure services like housing, water and sanitation services makes life in informal settlements unbearable. Such a characteristic provides both new challenges and opportunities in cities. Dealing with such informality provides new opportunities for city governance in which informality is embraced, tapped into and incorporated in the mainstream urban development agenda to promote sustainable and inclusive cities (Muchadenyika, 2015b). Opportunities to tap into informality include a wider social capital base, and inclusive imaginations of the city - which are all vital aspects in developing urban centres that are inclusive.

Diverse arguments on urban informality include informal planning and urban crisis (Roy, 2009a); exceptions to the order of formal urbanisation (Roy, 2005); conceptual and empirical diversity of informality
(Bunnell \& Harris, 2012); inadequacy of housing policies (Lemanski, 2014); and the genealogy of informality (Van Ballegooijen \& Rocco, 2013) among others. Primarily such arguments raise issues of definitions, planning challenges associated with informality and the role of policies in contributing to informality. Slum upgrading is one preferred method of addressing informality in cities across the world. As such, studies have focused on legalised land tenure (Handzic, 2010); community-managed micro-finance (Das, 2015); community-led slum upgrading (Tomlinson, 2015); location and spatial approaches (Olthuis, Benni, Eichwede, \& Zevenbergen, 2015); and participatory approaches (Majale, 2008) among others. The point of departure in this article is a comparative analysis of the role of urban policies, leadership and politics in slum upgrading.

Demolitions and slum upgrading have been the two main responses to informality by city and government authorities and international development agencies. Many African cities have implemented either of the two or both. Demolitions have attracted international condemnation and criticism (Fontein, 2009; Kamete, 2009; Potts, 2006, 2008); while slum upgrading has been considered as a more practical and humane approach to handling informality (Cirolia, Gorgens, van Donk, Smit, \& Drimie, 2016; Minnery et al., 2013; Muchadenyika, 2015b; Olthuis et al., 2015). As such, slum upgrading is increasingly becoming part of urban development policy (Syagga, 2011), and it has been

\footnotetext{
* Corresponding author.

E-mail address: muchadenyikad@gmail.com (D. Muchadenyika).
} 
Table 1

Urbanisation statistics for Harare and Kampala.

Source: UN-Habitat, 2014: 150; 225.

\begin{tabular}{|c|c|c|c|c|c|c|}
\hline City & Population (000 s) & $\begin{array}{l}\text { Average annual growth rate } \\
2010-2025(\%)^{\mathrm{a}}\end{array}$ & $\begin{array}{l}\% \text { of urban } \\
\text { population }\end{array}$ & $\begin{array}{l}\% \text { of total } \\
\text { population }\end{array}$ & $\begin{array}{l}\text { Average annual population increase } \\
2010-20(000 \mathrm{~s})^{\mathrm{a}}\end{array}$ & $\begin{array}{l}2025 \text { population } \\
(000 \mathrm{~s})^{\mathrm{a}}\end{array}$ \\
\hline Kampala & 1659 & 6.75 & 31.2 & 4.8 & 107.0 & 3.540 \\
\hline Harare & 1526 & 3.54 & 31.3 & 12.1 & 54.0 & 2335 \\
\hline
\end{tabular}

a Projections.

considered to be one of the effective ways of tackling urban poverty (Huchzermeyer, 2008; Minnery et al., 2013). For example, the upgrading and development of Nairobi's slums has improved access to basic services by the poor (Otiso, 2003).

This article focuses on the role of urban policies, politics and leadership in slum upgrading. Such a focus is through a comparative analysis of slum upgrading experiences in Harare (Zimbabwe) and Kampala (Uganda). Table 1 shows the urbanisation statistics between the two cities.

As shown in Table 1, both Kampala and Harare account for more than $30 \%$ of their respective country's urban population. Further, the average annual growth rate for Kampala and Harare stands at $6.75 \%$ and $3.54 \%$ respectively. This means among other things that competition for housing is immense. By 2025, population projections for both cities will nearly double. In line with the urbanisation statistics for Harare and Kampala, it is evident that issues of service provision (housing, water and sanitation among others) become more prominent.

The paper is divided into 7 sections. Section 1 briefly discusses the challenges of informality in Africa cities. Section 2 reviews extant literature on the role of policies, party-politics and leadership in slum upgrading; while Section 3 discusses the research methodology. Sections 4 and 5 discuss the paper's findings in the two African cities namely Harare and Kampala respectively. After that, the article compares and discusses the findings in Section 6, while Section 7 provides key conclusions and recommendations.

\section{Slum upgrading}

This section focuses on three things namely policy, leadership and party-politics in slum upgrading. By policy, we refer to statements of intent by either governments or municipalities particularly on the subject of housing and urban planning. Leadership is used to mean the behaviours of people mandated to manage cities. Tensions between political parties with the intention of weakening each other's political fortunes at the expense of sound city management and development is referred to in this article as party-politics. The three aspects of policies, leadership and politics manifest within a governance context. Governance means 'the web of formal or informal institutions, rules, norms and expectations which govern behaviour in societies' (Leftwich, 2004: 10). In particular, it 'involves deciding upon collective goals for the society and then devising the mechanisms through which those goals can be attained' (Peters, 2004: 25).

\subsection{Policy}

The role of housing policy is underscored by the World Bank (1993: 4) through stating that: 'governments should be encouraged to adopt policies that enable housing markets to work'. Despite this, in a study of Ho-Chi-Minh city in Vietnam, Coit (1998) argues that the urban policy disapproves slum upgrading. She further contends that officials in favour of slum upgrading were replaced by those less favourable. In such instances, where there is no policy support, chances of slum upgrading succeeding are therefore whittled. Many urban policies give preference to capital intensive urban redevelopment projects which often evict slum dwellers putting into motion extensive contestations and struggles. Neo-liberal approaches to housing views the city as an epicentre in which space is developed by the highest bidder. In this instance, issues of equality and social and spatial justice are submerged, in the process, marginalising the urban poor.

Using Mumbai as a case study, O'Hare, Abbott, and Barke (1998) demonstrate how housing policies (from 1986 to 1998) affect slum upgrading, the urban poor and overall city growth. In particular, the study concluded that policy responses are fundamental in dealing with the challenge of slums and squatter settlements. Further, Mukhija (2001: 220) argues that housing policies should prioritise 'in situ upgrading based on lot-readjustment, with or without limited demolition and resettlement'. From the above, procedures, principles and the framework guiding slum upgrading should form part of housing policy.

In Zimbabwe, one of the major policy decisions taken by the independent government was to upgrade Epworth, a largely informal urban settlement in 1983 (Ramsamy, 2006). In fact, 'the decision by the government not to bulldoze the informal settlement at Epworth but to upgrade in situ has major policy ramifications for the future with respect to the development of planning methodologies in Zimbabwe and to increasing the housing stock' (Butcher, 1995: 70). Such a policy led to the regularisation of 5000 housing stands through in situ upgrading (Chirisa, 2011). Despite this, Zimbabwe's housing policy stifled grassroots driven approaches to housing. For example Rakodi (1989: 11) characterises the post-1980 government approach to housing as one in which 'an already established black bourgeoisie appears set to protect its growing property interests ... insisting on high-quality construction for low-income residents effectively marginalising the poorest households'.

For the case of Uganda, in 1986, as part of the National Human Settlement Policy, the government embarked on two housing projects namely, Namuwongo Upgrading and Low Cost Housing Pilot Project in Kampala and Masese Self-Help Women's Project in Jinja (Government of Uganda, 2008). Nevertheless, as will be discussed in Section 5 these projects did not benefit the intended urban poor. Consequently, in 1992, the government developed the National Shelter Strategy (NSS) and adopted an enabling approach to improving housing conditions in the country (GoU, 2008; MLHUD, 2016b; Mukiibi, 2011). However, it has been argued that the NSS attained limited success due to poor implementation, attributed in part to limited institutionalisation of the housing policy framework, and limited role played by government in developing an effective housing market (Mukiibi, 2011). Although the government through the NSS adopted an enabling approach, numerous policy gaps exist. A case in point, the country lacks an urban policy to provide a general framework for development of urban areas, while the complex land tenure system is yet to be addressed (Bidandi \& Williams, 2016). Nevertheless, a new national housing policy was approved in 2016. The policy emphasizes the idea that housing provision primarily rest on private individuals, with government creating an enabling environment, through among others formulation and implementation of policy, setting standards and mobilising resources.

\subsection{Politics}

On the global level, slum upgrading has been riddled by politics of interests, in particular, neoliberal principles of private property and 
market institutions (Jones, 2012). Most slum upgrading initiatives funded by foreign capital are often victims of such interests. For instance, in the 1970s many governments of developing countries abandoned their obligation of addressing the challenge of slums. As such, the World Bank took the lead in funding slum upgrading schemes in various developing countries, which gave the Bank an opportunity to influence national urban policies of these countries by imposing its own ideologies as a yardstick to global urban policy (Davis, 2006).

Most slum upgrading programmes across Sub-Saharan Africa have been externally funded, leading to a direct influence of policies by external players most especially the international development agencies. A heavy reliance on external slum upgrading financing presents numerous sustainability questions that relate to the design, maintenance of infrastructure during and after upgrading, and scalability of slum upgrading programmes. For example, in India, the Indore Habitat Improvement Project - a slum networking project launched by the Indore Development Authority with funding from the Overseas Development Administration of the British Government (currently known as Department for International Development), suffered sustainability challenges. This was attributed to the over reliance of the project on external funding to cover capital costs of the project, with the expectation that the municipal authority (not directly involved in the implementation of the project) could take on maintenance of the upgraded infrastructure even with no clarity on roles and responsibilities. Moreover, the project did not provide for the participation of slum dwellers in the planning or financing of the project (Tripathi, 1999). This signalled challenges in post-project maintenance of the project infrastructure (Verma, 2000). Nevertheless, in successive slum upgrading projects in other cities in India (Baroda, Ahmedabad, Mumbai and Bhopal), the concept of slum networking evolved with less reliance on donor support (Diacon, 1997), and the adoption of slum community participation (Parikh, Surkar, \& Zanders, 2003; Tripathi, 1999) to promote self-sufficiency and greater degree of community control, and financial self-sufficiency as experienced in Baroda and Ahmedabad respectively (Diacon, 1997).

At a national level, politics normally plays out among stakeholders such as government, non-governmental organisations (NGOs), private sector and slum dwellers. In Nairobi, Kenya, stakeholders (government, private and voluntary sector) managed to deal with the negative impacts of politics through capitalising on each actor's comparative advantage and transcending sectoral limitations (Otiso, 2003).

Addressing informality requires politics of inclusion characterised by institutionalised participatory and organised urban citizenship (Roy, $2009 \mathrm{~b})$. It is through violent and non-violent tactics that the urban poor confronts, negotiates and advocates for inclusive politics (Muchadenyika, 2017). Slum settlements are often used as sources and resources for political agency, explaining why many such settlements are politically charged. Programmes or initiatives to upgrade slum settlements are often entangled in politics (Muchadenyika, 2015b; Otiso, 2003). In many cases, failure to deal with politics threatens the success of slum upgrading programmes.

\subsection{Leadership}

There are two forms of slum upgrading viz. community-led and government-led. Literature points to the failure of government-led upgrading initiatives due to resistance, and a lack of ownership and community participation (Kamete, 2013; Minnery et al., 2013). The most appraised approach in literature and practice remains communityled slum upgrading (Tomlinson, 2015; Tibaijuka, 2009; Patel, 2013; Muchadenyika, 2015b). However, the success of community-led upgrading requires political will and inclusive leadership. Such leadership is a responsibility of city authorities and government. In this regard, it has been argued that slum upgrading approaches should include 'changes to urban governance so that community capital can be maintained and improved over the long term' (Minnery et al., 2013:
162). Governance arrangements should not only support slum upgrading; rather, these should allow for participation, learn from and interact with the urban poor and partner with slum dwellers based on respect and mutual trust.

The above discussion points to the importance of inclusive municipal governance in slum upgrading. Inclusive governance 'emphasises on governance arrangements that promote the inclusion of people, in particular, the poor and marginalised' (Muchadenyika, 2015b: 2). In particular, inclusive governance is 'anchored on new structures and processes of engagement which are friendly and specific to the needs of the poor' (ibid). Inclusive municipal governance operates in an environment in which municipal officials, elected and appointed, are open to new learning, embrace criticism and champion new alternatives.

\section{Research methodology}

The paper aims to understand the role of policy, politics and leadership in slum upgrading. As such, the main research question that guided the study is: How does policy, politics and leadership affect slum upgrading? Data for this paper were collected through semi-structured interviews with city and government officials, representatives of slum federations and NGOs, mayors, councillors and slum dwellers (Table 2). In total 16 interviews were conducted between May and December 2015. In undertaking the study, different ethical measures were employed: Informed consent was sought before conducting the interviews. These interviews were conducted after informed consent. Moreover, respondents' information was treated with outmost confidentiality, and in cases where commentaries have been used, names of the respondents have not been reflected to ensure anonymity. In order to improve on credibility of the findings, excerpts from respondents commentaries are quoted verbatim.

The focus of the interviews was premised on slum upgrading experiences and in particular, the role of policies, politics and leadership. The study also employed document analysis through which government legislations and policies on urban housing, planning, land and slum upgrading in Uganda and Zimbabwe was conducted. Document analysis at city level drew from, council resolutions, annual reports, and slum federations reports.

The paper compares two cities namely Harare and Kampala because of five reasons. First, both cities are predominantly run by opposition parties with the central government exerting undue political interference (Muchadenyika \& Williams, 2016; Resnick, 2014). Such a political construction brings inter-party tensions in particular on the planning and management of city affairs. Second, both cities have

Table 2

List of interviewees.

Source: Authors' Fieldwork, 2015.

\begin{tabular}{lll}
\hline Name & Position and organisation & Date of interview \\
\hline A1 & Councillor, City of Harare & 15 August 2015 \\
A2 & HSUFF official & 19 August 2015 \\
A3 & Housing officer, City of Harare & 13 September 2015 \\
A4 & Planning Officer, City of Harare & 25 October 2015 \\
A5 & Housing Manager, City of Harare & 14 October 2015 \\
A6 & ZIHOPFE Coordinator & 2 December 2015 \\
A7 & ZIHOPFE member & 15 November 2015 \\
A8 & Senior Housing Officer, City of Harare & 29 October 2015 \\
A9 & Namuwongo LC 1 Chairperson & 18 May 2015 \\
A10 & KCCA Supervisor Development Control & 15 July 2015 \\
A11 & Executive Director of ACTogether & 20 June 2015 \\
A12 & Metal fabricator, Soweto Slum Kampala & 25 May 2015 \\
A13 & Female market vendor & 25 July 2015 \\
A14 & KCCA Deputy Director of Physical Planning & 19 May 2015 \\
A15 & KCCA Deputy Director Gender, Production and & 15 June 2015 \\
& Community Services & \\
A16 & Member, National Slum Dwellers Federation of & 20 June 2015 \\
& Uganda &
\end{tabular}


Table 3

Population and housing statistics for Harare.

Sources: Zimstat, 2012; Muchadenyika, 2015b; COH DUPS, 2012; COH DHCS, 2012.

\begin{tabular}{|c|c|c|c|c|c|c|}
\hline Variable & Population & Population growth (p.a) & Housing stock & Housing backlog & Number of slums & Population living in slums \\
\hline Number & $1,485,231$ & $5.8 \%$ & 240,000 & 500,000 & 62 & 165,609 \\
\hline
\end{tabular}

conducted slum upgrading programmes which makes it imperative to compare processes and outcomes. Third, both cities are characterised by tenuous relations between the city authorities and the national government over power, authority and influence. Fourth, both cities face challenges of high unemployment. For example the unemployment rates for Harare and Kampala stands at $27.6 \%$ and $11.4 \%$ respectively (UN-Habitat, 2016). Lastly, the percentage of the total urban population in Kampala and Harare is estimated to be $31.2 \%$ and $31.3 \%$ respectively (UN-Habitat, 2014). From the above, high unemployment rates and the fact that the two cities constitute a greater percentage of the total urban population means that issues of housing and related services to the urban poor are pertinent.

\section{Harare}

Harare is Zimbabwe's capital and has an estimated population of $1,485,231$ (Zimstat, 2012) against a formal housing stock of 240,000 (Table 3). Table 3 shows housing challenges characterised by 62 slums accommodating about 165,609 within Harare city. Post 2000, the housing challenge in Harare is marked by a sharp decline in the technical and financial capacity of the city to provide housing, in particular, for the urban poor (Muchadenyika, 2017). In the post-2000 era, the city has not delivered a single housing unit due to financial and technical challenges (Ibid). However, the major actors in delivering housing became self-help groups, in particular, housing co-operatives. For example, between 2000 and 2015, housing co-operatives delivered 34,000 housing units (Muchadenyika, 2017). During the same period, government delivered 637 housing units (POZ, 2006).

\subsection{Slum upgrading}

Slum upgrading in Harare is a partnership among the City of Harare, Zimbabwe Homeless Peoples Federation (ZIHOPFE) and Dialogue on Shelter. ZIHOPFE is predominantly a women's movement advocating for low-cost housing delivery approaches to the urban poor. As of 2014, ZIHOPFE had facilitated access to housing stands by 15,000 households in Zimbabwe's 52 local authorities (Muchadenyika, 2015b: 4). It is supported technically and financially by Dialogue on Shelter, a Zimbabwean NGO. The Harare Slum Upgrading Programme (HSUP) is a 5 year project supported with a grant of US\$ 5 million from the Bill and Melinda Gates Foundation. The direct impacts of slum upgrading have been transformation of 480 poor households through secure tenure and infrastructure services (ibid); set-up of pro-poor housing finance

Table 4

HSUFF and housing loan financing (as of March 2016).

Source: Calculated from Dialogue on Shelter database.

\begin{tabular}{llll}
\hline Indicator & $\begin{array}{l}\text { Home } \\
\text { improvement }\end{array}$ & $\begin{array}{l}\text { Income } \\
\text { generation }\end{array}$ & Totals \\
\hline $\begin{array}{l}\text { Total amount disbursed } \\
\text { Total loans issued }\end{array}$ & US\$176.900,00 & US\$126.000,00 & US\$305.900,00 \\
$\begin{array}{c}\text { Total outstanding } \\
\text { amount in loans }\end{array}$ & - & 102 & 193 \\
$\begin{array}{c}\text { Number of outstanding } \\
\text { loans }\end{array}$ & - & - & US $\$ 114.769$ \\
$\begin{array}{l}\text { Repayment rate } \\
\text { Total number of loan } \\
\text { groups }\end{array}$ & - & - & 99 \\
\hline
\end{tabular}

facility, adoption and implementation of a slum upgrading strategy which is assisting in city-wide slum upgrading (Muchadenyika, 2017). Other indirect impacts are the adoption and implementation of in situ upgrading in Epworth, and adoption of slum upgrading in other urban centres such as Bulawayo, Kadoma, Masvingo, and Kariba (ibid). In succeeding sections the article underscores the role of policy, politics and leadership in the HSUP.

\subsubsection{Policy}

Policies determine how cities are planned and governed. However, in most instances, policies do not necessarily reflect on issues to do with slum upgrading. This is true, as well in the context of Harare as discussed here. In this regard, 'the City of Harare underscored the necessity of policy changes to support slum upgrading' (A1). The city adopted the Harare Slum Upgrading Strategy (HSUS) which provided changes to three aspects of slum upgrading namely planning, finance and infrastructure. ${ }^{1}$

There has been a drastic decline in low-cost housing finance in Zimbabwe in the post-2000 era. This development left the urban poor vulnerable to high-cost housing finance, which in many instances is unaffordable. Thus, the City of Harare, with its slum upgrading partners initiated a pro-poor housing finance facility. The purpose of the facility is to finance city-wide slum upgrading initiatives. The 'financial facility is a revolving fund for slum upgrading and pro-poor housing development where donor agencies would contribute financially to the fund'.2 The city provided 'an initial capital of US\$ 120.000 with ZIHOPFE and Dialogue on Shelter providing US\$ 80.000' (A2). Access to the fund by the urban poor and its contributions to incremental upgrading is presented in Table 4. In other words, the finance facility is the main vehicle financing slum upgrading activities at the city-wide level. The facility provides loans for four activities mainly land purchase, home improvement, income generation and water and sanitation. ${ }^{3}$

On infrastructure, the city adopted incremental development policy. This means the provision of infrastructure services gradually over time viz. 'from communal water and sanitation facilities to household facilities' (A5). Equally, incremental development allowed 'the development of housing from transitional houses made of shacks and plastics to planned brick and mortar structures' (A3). Such a policy appreciates the inherent constraints faced by the urban poor during slum upgrading. To facilitate the work of urban poor groups, the city adopted a policy on procurement of infrastructural construction materials and equipment with community based organisations and co-operatives accessing free gravel; and hiring council equipment at concessionary rates. ${ }^{4}$

One of the challenges facing planning and housing delivery in Zimbabwe is bureaucratic planning procedures (GoZ, 2009, 2012). In trying to streamline such procedures, the city reviewed its planning procedures and regulations. Despite this, the review process could not yield result as it concluded 'that administrative improvements are needed more than actual review of regulations'. ${ }^{5}$ However, changes are a process over time, and can be done incrementally, for instance,

\footnotetext{
${ }^{1}$ Harare Slum Upgrading Strategy, adopted on the 1822nd Ordinary Council Meeting, 8 November 2012.

${ }^{2}$ City of Harare Finance and Development Committee Minutes, 17 March 2014.

${ }^{3}$ Harare Slum Upgrading Finance Facility Manual.

${ }^{4}$ Harare Slum Upgrading Strategy, adopted on the 1822nd Ordinary Council Meeting, 8 November 2012.

${ }^{5}$ City of Harare Review of Planning Regulations and Plan Approval Processes, July 2012.
} 
though implementing pilot projects using reviewed planning regulations (Muchadenyika, 2015b). Thus, existing planning regulations and procedures, in particular lengthy and tedious layout plan approval processes remain a major stumbling block to slum upgrading.

Borrowing from the HSUP and also in the interest of facilitating slum upgrading nationwide, the 2012 National Housing Policy adopted incremental development as a low-income housing development strategy. The policy defines incremental development as a 'housing development strategy which allows the developer to start constructing essential services such as water and sanitation and allow beneficiaries to occupy their stands' (GoZ, 2012). Partly, this explains why slum upgrading has been adopted in a number of urban centres in Zimbabwe including Epworth, Kadoma, Bulawayo, and Kariba where initial processes of slum profiling, mapping and enumeration have been conducted (Muchadenyika, 2017). Responsible local authorities in these urban centres are intrinsically using incremental development as a fundamental slum upgrading strategy.

\subsubsection{Politics}

Land and, in particular, for housing in Zimbabwe's urban centres is politicised and widely contested (Muchadenyika, 2015a). There is a distinctive role of politics in the allocation of housing land in Harare. In this regard, 'evidence suggests that land is allocated along political party affiliations' (A1). At the same time, the Government of Zimbabwe and City of Harare have not significantly delivered new housing stock in Harare in the post-2000 era. As such, there is an immense shortage of low-income housing which is worsened by a two decade long socioeconomic and political crisis.

In Harare's contested political environment, 'the genesis of slum upgrading provided an opportunity for political parties to entrench their interests' (A1). Slum upgrading was initially targeted to renew and upgrade hostels in the oldest settlement in Harare, Mbare. However, the Zimbabwe African National Union Patriotic Front (Zanu-PF) militia group in control of Mbare resisted the programme agitating for slum upgrading to cede $51 \%$ of the outputs to its members (Muchadenyika, 2015a). The militia group is also in control of marketing stalls and bus termini and collecting levies in Mbare usurping the mandate of the city of Harare (Kriger, 2012; McGregor, 2013). As a result, 'all three main partners agreed on and took practical steps towards depoliticising slum upgrading' (A4).

Due to political reasons, the City of Harare, ZIHOPFE and Dialogue on Shelter decided to move the HSUP to Dzivarasekwa (COH DHCS, 2012), where slum dwellers had settled since 1991. This was 'a strategy to diffuse political tensions in Mbare' (A5). Further, 'the Federation as a movement is apolitical, in terms of its rituals - something that contributed in diluting the negative impacts of politics during slum upgrading' (A6). The rituals of ZIHOPFE became fundamental in dealing with politics. This is, however, not to discount that slum dwellers in Dzivarasekwa have no political affiliations. They do have though 'in Federation activities, it is strictly apolitical' (A7). During interviews with movement members, it was indicated that they come from various political persuasions but work together through an apolitical movement (A2, A6, A7). Slum dwellers across the political divide shared their concern on how politics destabilises development and hence, 'electing to leave politics aside on development matters' (A5). In addition, 'slum upgrading in Dzivarasekwa targeted both Federation and non-Federation members; which in itself was inclusive and weathered potential political hostilities from existing settlers on the land' (A7).

\subsubsection{Leadership}

Slum upgrading in Harare began after a long and ruthless antisquatter history within the city epitomised by the infamous Operation Restore Order of 2005. The Operation destroyed the majority of lowincome housing deemed illegal by the city and government (Muchadenyika, 2017). How could a city with such a history begin to lead and adopt slum upgrading as a low-income housing development strategy? Perhaps, as we argue in this paper, this is partly because of focused and dedicated political and administrative leadership within the City of Harare.

The Mayor of Harare, Muchadei Masunda (2008-13), became the flag bearer of slum upgrading within the city. The mayor was open to views from different groups within the city regardless of social, political and economic status (A7). The mayor himself was not a known member of the two contesting parties - the Movement for Democratic Change and Zanu-PF. Further, 'the mayor held meetings with slum dwellers in slums, cultivating mutual trust between the city and slum dwellers' (A7). Of particular to note is the "open door policy" of the Mayor of Harare who actively engaged with the Federation, Gates Foundation, city and government officials from the initial discussions on slum upgrading (Muchadenyika, 2015b: 5).

In this context, the political leadership of the City of Harare sufficiently put slum upgrading on its governance agenda (discussed in detail under Section 4.1.1 on policies adopted to facilitate slum upgrading). Such strategic leadership in slum upgrading, led to the Mayor of Harare being awarded the UN-Habitat Scroll of Honour award. The Award 'encourages and recognises the countries, governments, organisations and individuals who have made great contributions to the development of housing, ${ }^{6}$ UN-Habitat posits that the award is the most prestigious human settlements award in the world set out in 1989 to acknowledge outstanding contributions to shelter provision, addressing plight of the homeless, and improving quality of urban life.

The City of Harare's administrative departments provided immense leadership during slum upgrading. The housing directorate, as the focal department for slum upgrading 'went through a process of relearning' (A8). This entailed 'threading off the conventional way of treating slum dwellers as "urban nuisance" (A8). The department also became the focal point for inter-city departmental coordination. In this way, "the department played a vital role in convincing other departments, for instance, urban planning and engineering which showed immense resistance during initial upgrading stages' (A3). In summary, the housing department incubated slum upgrading as its baby - defending it to the hilt.

\section{Kampala}

Kampala is the capital city of Uganda and has an estimated population of 1,507,114 (Uganda Bureau of Statistics, 2016). However, the city's population is projected to increase to at least 10 million people in the next two decades (KCCA, 2012; World Bank, 2015). Given the exponential increase in urbanisation, coupled with limited supply of housing and access to housing finance, Kampala faces an enormous housing deficit. The provision of housing in Kampala and Uganda in general is mainly through the private sector (World Bank, 2015), since the housing sector has been left to be determined by market forces which in this case do not favour substantial investment in affordable housing (GoU, 2008). As such, driven by the need to generate profit, the private estate developers only target the housing needs of the high-and middle-income earners, while leaving out the low-income earners to be provided for by the informal sector (ibid). With only an $11 \%$ increase in housing stock over a four period (2011-2014), Kampala's housing deficit has increased from 65,054 units in 2011 to 73,388 units in 2014 (see Table 5). This implies that by 2014 Kampala contributed $38 \%{ }^{7}$ and $9.7 \%$ to the total urban and national housing deficit respectively.

The housing deficit in Kampala is exemplified by the increase in the number of slums and bulge in slum population. Currently, the city has 62 slums spread across the city (Jones, Bird, Beck, \& Haas, 2016; KCCA, 2014), accommodating over $60 \%$ of the city's residents (Brown, 2012;

\footnotetext{
${ }^{6}$ https://unhabitat.org/urban-knowledge/awards/.

7 Total urban housing deficit at this percentage is a product of the summation of the housing deficit of Kampala and other urban areas in Uganda (170,570 housing units).
} 
Table 5

Housing deficit in Uganda.

Source: MLHUD, 2015.

\begin{tabular}{lllll}
\hline Period & Kampala & Other urban areas & Rural areas & National \\
\hline 2011 & 65,054 & 105,516 & 519,465 & 690,035 \\
2012 & 67,721 & 110,370 & 532,451 & 710,542 \\
2013 & 70,497 & 115,447 & 545,763 & 731,707 \\
2014 & 73,388 & 120,758 & 559,407 & 753,552 \\
\hline
\end{tabular}

Brown, 2014; Lwasa, Nyakaana, \& Segendo, 2007; Mukiibi, 2012; World Bank, 2015). Most of these slums are located on prime land suitable for economic and infrastructural development (Brown, 2014), hence increasing the vulnerability of slum dwellers to eviction by developers.

\subsection{Slum upgrading}

Kampala City has witnessed mainly two significant slum upgrading projects. In 1986, with support from UN-Habitat, the government embarked on the Namuwongo low-cost housing slum upgrading project in Makindye Division. This project was aimed at improving the living conditions of the slum dwellers by offering them access to better housing. However, the conditions given by the project partners were unfavourable to slum dwellers especially the poor. For example, one had to pay 200,000 shillings (equivalent to US $\$ 138$ at the time), to be awarded an allocation letter for a plot of $325 \mathrm{~m}^{2}$. Moreover, one was given a specified period in which to construct a house based on the approved plan and materials. Due to these exclusive conditions, 'the tendency was the poor selling their plots and shifting to other slums, while others extended further into Namuwongo swamp and established another slum' (A9). As a result, the project failed to meet its objectives as the rich rather than the intended slum dwellers benefited from the project.

Furthermore, in 2003 the government through the Department of Human Settlements, in collaboration with Slum Dwellers International (SDI) launched the Slum Upgrading Program (SUP) in three parishes (Kisenyi I, Kisenyi II \& Kisenyi III) of Kampala Central Division. The project was aimed at among others conducting slum profiling, housing demonstrations sensitisation, mobilising communities into saving and loans schemes and infrastructure development (GoU, 2008). Though it is always envisaged that lessons learned from these projects could be replicated in other informal settlements in Kampala, scaling up such slum upgrading initiatives from pilots to wider city-level programme has been problematic. This is attributed to 'among others limited financial resources, complex land tenure system and politicisation of slum upgrading to gain political expediency' (A14). As such, slum upgrading has been implemented through isolated projects with limited city wide impact. Similarly, KCCA (2012) argues that current slum upgrading attempts in Kampala city and Uganda in general have been mainly localised and lack any comprehensive spatial vision or wider context.

Currently, government's slum upgrading efforts have been directed to secondary cities including Arua, Jinja, Mbale, Mbarara and Kabale, through the Transforming Settlements of the Urban Poor in Uganda programme (TSUPU). This programme is a partnership between the Government of Uganda and Cities Alliance aimed at managing rapid urbanisation and improving living conditions of the urban poor (MHLUD, 2013a; MHLUD, 2016a). This programme excludes Kampala city. In Kampala, most slum upgrading activities have been undertaken mostly by NGOs most notably ACTogether, a support organisation for the National Slum Dwellers Federation of Uganda (NSDFU). This organisation in partnership with Slum Dwellers International (SDI) works with slum communities to support community-led savings and loan groups, community exchanges, house model exhibitions, slum upgrading pilot projects, and advocating for the rights and voice of the urban poor.

Given the magnitude of slum areas in the city, efforts from NGOs are therefore inadequate. Thus, 'the current slum upgrading efforts in the city are fickle and done in a piecemeal manner' (A10). Moreover, 'little has been done with regards to physical slum upgrading' (A11) partly due to the city's complex land tenure system. However, KCCA plans to upgrade slums in Kampala, with emphasis to be placed on slums located on government land (Ssenyonga, 2016). It is important to note that, about $58 \%$ of the land on which slums are located is privately owned (Dobson, Lutwama, \& Mugisa, 2014), whereas 52\% of the total land in Kampala is privately owned (Giddings, 2009). Inspite of this, KCCA plans to work with the land owners to have their land developed (Ssenyonga, 2016), as the majority of landowners lack adequate funds to develop their land (Dudwick, Hull, Katayama, Shilpi, \& Simler, 2011). However, after the failure of Namuwongo housing project 'slum dwellers are sceptical about government's housing projects and have less hope that such initiatives will benefit them' (A12).

\subsubsection{Policy}

Uganda has a number of policy and legal frameworks that deal with slum upgrading and the prevention of slum proliferation. For example, the National Slum Upgrading Strategy and Action Plan (NSUP) was developed in 2008 to guide slum upgrading in the country. The strategy outlines a framework and plan for concerned stakeholders with an aim of uplifting the lives of at least one million people by the year 2020. The main thrust of this strategy is to ensure that slum upgrading and redevelopment efforts are integrated into national policies, legislation, and programmes to enable their implementation. The argument presented is that slum upgrading should not be viewed as a special aspect in broader national development plans, but should be clearly integrated in government plans and programmes on the basis of its objectives and principles (GoU, 2008). Although the NSUP has gained traction by the adoption of slum upgrading into the National Development Plans (NDP) and Kampala Physical Development Plan (KPDP), implementation of slum upgrading especially in Kampala lags behind.

Going forward, the government approved a new National Housing Policy (NHP) in 2016. This policy replaces the National Shelter Strategy (NSS) developed in 1992 that had adopted an 'enabling approach' as a major policy objective (MLHUD, 2016b). The main thrust of the NHP is to revitalise the housing sector in Uganda and ensure access to adequate housing for all Ugandans. As such, it proposes a number of strategies including among others: harmonising existing housing related policies, laws and regulations; establishing a functional institutional framework for effective housing delivery; improving land tenure security; increasing access to adequate and affordable housing; developing programmes for affordable housing in urban areas, and improving the living conditions in slums at the same time preventing future slum development (ibid).

Even with the existence of the aforementioned policy interventions, gaps still exist in the housing sector and slum upgrading processes in Kampala and the country at large. A case in point, there is an ineffective policy framework guiding urban development in Uganda (MLHUD, 2016a), due to the absence of an urban policy to guide the growth and development of urban areas. Although a draft policy currently exists, the process of the development and approval of this policy has stalled for over five years. Similarly, the "policy and legal framework for the housing sector is inadequate and scattered under different instruments, which makes it hard for the sector to effectively implement them' (MLHUD, 2016b: 9).

Important to note also, is the intricate land tenure system provided for by the Land Act of 1998 that is characterised by dual legal regimes and multiple land administration and conflict resolution structures. Article 237(1) of the 1995 Constitution of Uganda, and the Land Act of 1998 (section 2), spells out that land belongs to the citizens of Uganda and should be held in accordance to four land tenure systems including, 
Customary, Freehold, Mailo, and Leasehold (GoU, 1998). The Act also provides for the rights of lawful and bonafide tenants to make transactions (with the consent of the land owner) over registered land while it orders the owner of the land in the event of selling to adequately compensate the occupants. Although this move enhanced the tenure rights of the citizens especially the poor, it created multiple land interests over land, which affects urban land access, planning and development in the city (Dobson et al., 2014; Goodfellow, 2013; John Paul II Justice and Peace Centre, 2011; Lall, Henderson, \& Venables, 2017; MLHUD, 2013a; Musisi, 2017).

The multiple and competing rights over land has often fuelled rampant land disputes and evictions. This has hindered land and housing investments as proper operation of both land and housing markets are grossly affected (Bernard, Bird, \& Venables, 2016; Jones et al., 2016; Musisi, 2017). Until the land question is addressed, the challenges of housing development and slum upgrading in Kampala city will remain unabated.

\subsubsection{Politics}

Kampala's political landscape is characterised by political contestations between the ruling National Resistance Movement (NRM) government and the opposition political parties led by Democratic Party (DP) and Forum for Democratic Change (FDC). Until 2010, Kampala was governed under a decentralised system with the mayor having both political and administrative powers over city affairs. In 2011, the central government took over the governance of the city through the enactment of the Kampala Capital City Act of 2010. Although the government stated that the maladministration under Kampala City Council (KCC) prior to 2011 prompted government's takeover of the city's administration (Karyeija \& Kyohairwe, 2012; KCCA, 2014; World Bank Group, 2015); other scholars argue that the move was intended to neutralise the opposition's domination and influence in the city (Goodfellow, 2013; Lambright, 2012). Under section 3(2) of the KCCA Act, the power to govern the city is vested in the central government. Moreover, the KCCA is established as a body corporate charged with the responsibility for administering the city on behalf of the central government. The KCCA Act 'significantly reduced the Mayor's powers, and many responsibilities to manage the city were transferred to the newly created offices of the Executive director and Minister for Kampala Capital City, both appointed by the president' (A11).

However, the Act resulted in the creation of parallel lines of power between the Lord Mayor and the Executive Director leading into relentless conflicts arising from power struggle between these two office bearers (Karyeija \& Kyohairwe, 2012). Since the enactment of the KCCA Act, the opposition has maintained the office of the Lord Mayor, hence fuelling more conflict. Due to the power struggles and political contestations, and factionalism characterising Kampala city politics, 'leaders often resort to using opportunist tactics for political expediency' (A9). Such a political environment has resulted into time and effort being spent on political battles, rather than on addressing urban development challenges such as slums. A market vendor indicated that 'our leaders spend time in wrangles other than dealing with our problems' (A13). The on-going struggles and tensions at KCCA have created an unfavourable environment for tackling city problems. Each of the warring side trade accusations and engage in perpetual court battles.

The political contestations within KCCA's leadership have led to mistrust between city leaders. Lack of trust 'makes it difficult to cooperate especially on city programmes implemented in slums' (A15). Instead of collaborating to seek solutions to address the problems faced by city residents, leaders are entangled in distributive politics and interparty power struggles. There has been 'limited motivation and commitment of the city's political and administrative leadership to work together to address the city's challenges including the housing deficit and slum development' (A14). Asiimwe (2016) avers that in Kampala coherence and coordination is weak due to the unwillingness of city leaders to work together to address city problems including slum development. Otieno (2011) posits that successful slum upgrading is not a political project, but rather a long term process that must be supported by all stakeholders despite conflicting interests. However, this has not been the case in Kampala, as the power struggle between the political and administrative heads of the city has culminated in both parties running city affairs in a parallel fashion, with each claiming to be the legitimate authority at KCCA (Asiimwe, 2016). Political contestation affects participatory slum upgrading and community inclusion, as the community is divided along political lines which reduces cohesion needed for successful slum upgrading.

\subsubsection{Leadership}

The nature of city leadership is a key ingredient in the realisation of slum upgrading goals. As such, Asiimwe (2016) affirms that city leaders are expected to embrace collaborative leadership in their governance. Despite this, city management in Kampala is highly politicised and currently the city experiences a leadership crisis that impinges on the implementation of development programmes (A9). In fact, 'the contentious nature of urban politics is perhaps the major deterrent to the city's efforts towards upgrading' (A14).

Furthermore, there is little appreciation of slum upgrading and physical planning by political leaders both at city and national level. As such, there is limited prioritisation and allocation of funds for slum upgrading. A town planner in the physical development directorate of KCCA argued that '...some Members of Parliament think that funds spent on physical planning could be put to proper use through provision of services.... as a result planning is not prioritised'(A14). In agreement, MLHUD (2013b) indicates that physical planning has not been given due attention at local government levels, despite the benefits that accrue to it like managing and regulating development to conform to stipulated policies and standards. According to Huchzermeyer (2008), the crucial component lacking for slum upgrading is political will. This is attributed to a lack of common interest among government officials and the existence of opportunities for rent-seeking which limit the efforts made by government officials towards achieving public goals (Ibid).

Leadership challenges in Kampala city coincide with limited grassroots movements championing slum upgrading in the city. Archer (2009) argues that the strength of leadership preceding the upgrading process can be regarded as a stock of social capital. Successful upgrading requires solidarity and partnership between slum movements and city leaders. However, key informants interviewed expressed concern about the dysfunctionality of local leadership (A10, A14, A11). An official from KCCA indicated that 'local leaders hold you at ransom, they do not let you access the community...you don't know whose interest they are pursuing... you don't know whether what you say to them is actually what they pass on to the community'(A15). Similarly, a resident of Soweto slum argued that 'the challenge in Kampala is poor leadership, all our leaders right from the local council (LC) level to the city level are greedy and selfish' (A12). In this regard, community leadership is vital in rallying the support and legitimacy for slum upgrading programmes.

The nature of governance at community or LC level in Uganda has also resulted in tensions within communities. Primarily this is because 'there has been no change in leadership at community level in the country for over a decade and there is no political will to do so, since the change does not serve the political interests of the seating national government' (A9). ${ }^{8}$ This has resulted in an 'inefficient functioning of

\footnotetext{
${ }^{8}$ The election for Village LC 1 and LC2 are planned for 21st November 2017. Nevertheless, different from the voting procedure spelt out under the Local Government Act that requires the election of LC 1 and 2 to be through a secret ballot, the NRM dominated parliament passed the Local Government Amendment Bill, 2014 to provide for queuing behind candidates.
} 
local leadership systems at local level, as residents no longer feel attached to them' (A12). In this regard, LCs have lost respect in the community. In addition, local council leaders are not facilitated by government, and do not receive specialised training to boost their capacity to perform their duties. As such some local leaders no longer call for meetings or sensitise communities. Efforts by political leaders to address these challenges have often resulted into conflicts. For instance, in Makindye division, the Resident City Commission (RCC) appointed local leaders resulting into what the community call 'Original LCs' (Long serving) and 'Duplicate LCs' (referring to the appointed). This new creation has created confusion and conflict among community members (A16). Without stable, trusted and well facilitated governance structures at local level, mobilisation of communities for slum upgrading becomes a challenge. Marx, Stoker, and Suri (2013) argue that slum upgrading cannot take place without the political willingness to change governance dynamics in slum areas and dealing with the actors that govern such areas in the absence of the government.

For slum upgrading to succeed, the participation of the slum dwellers is fundamental. Nevertheless, due to limited participation and involvement of slum dwellers, little information regarding slum upgrading exists among slum communities in the city. This is evidenced by one of the slum dwellers who said that, 'we are not aware of KCCA's plans concerning the planned development in slums and our rights as tenants' (A9). This was confirmed by a KCCA official who argued that, 'the local residents have not been sensitised on the slum upgrading strategy, and as such little trickle down of information on the strategy exists' (A10).This information gap is often exploited by opportunistic leaders and individuals for personal gains (A11). However, the idea of municipal and settlement development forums championed by ACTogether-Uganda with support from SDI, holds promise for the greater participation of slum dwellers and acting as an information dissemination platform. During these forums 'slum dwellers debate on priorities, exchange views, and agree on common actions together with the city leaders and other stakeholders' (A11). The forums have also been used as a platform to mobilise savings among slum dwellers through NSDFU. In support of the above, Dobson et al. (2014) argue that equipping a wider base of citizens with actual information can help to counter the tendency for rumour and unverified information.

\section{Discussion and analysis}

In comparing slum upgrading experiences between Harare and Kampala; we underscore five issues, namely, international development finance, constitutional and legal framework, national and city level policies, inclusive city leadership and land institutional arrangements. The US\$ 5 million grant from the Gates Foundation was instrumental in setting into motion slum upgrading in Harare. Without such a grant, 'slum upgrading could not have been possible considering the financial challenges facing the City of Harare' (A3). It can therefore be argued that international development finance is fundamental in supporting slum upgrading as most African cities are financially constrained to budget for and finance slum upgrading. In Kampala, slum upgrading has been muted largely due to a lack of considerable financing for upgrading, and the complex land tenure system.

City-level policies are fundamental in providing a framework for slum upgrading. In Harare, the HSUS outlines the policy framework for slum upgrading including upgrading financing. In this regard, 'the policy provided for the setup of a pro-poor housing finance, which is upscaling slum upgrading city-wide' (A2). In addition, the finance facility pools slum upgrading finance from domestic actors namely the city council, slum dwellers and local NGOs. Collaborative financing of slum upgrading allows joint ownership and sustainability of upgrading programmes. Grassroots-centred principles underpinning city-level policies on slum upgrading in Harare were also adopted at the national level. Such adoption is key in influencing slum upgrading nation-wide. In comparison, Kampala city 'did not take the advantage of internalising and localising national level policies and frameworks on slum upgrading at city level' (A10). In this case, the paper argues that internalisation of national policies at city level provides municipalities with guiding policy frameworks and protocols on slum upgrading.

The protection of the rights of slum dwellers in constitutions and national policies is vital. The Constitution of Zimbabwe has provisions that advance the rights of the homeless and these relate to Sections 28 (Shelter), 74 (freedom from arbitrary eviction) and 77 (right to food and water) (GoZ, 2013). In addition, Zimbabwe's National Housing Policy adopts a 'no eviction without alternative' policy framework (GoZ, 2012) which can be interpreted to mean protection of slum dwellers' rights. In Uganda, the constitution does not specifically protect housing as a human right. In addition, 'the constitution is silent on the rights of slum dwellers, thus leaving them vulnerable to arbitrary evictions' (A11). The Constitution of Uganda and Land Act only protects bonafide and lawful occupants from evictions. Here, we argue that slum upgrading should not be conceived as just the physical transformation of slum settlements. Rather, it should also prioritise the rights of slum dwellers. In the absence of slum upgrading programmes, a rights-based perspective becomes fundamental in providing services in slums and also recognising the dignity of slum dwellers as equal human beings. In this regard, a rights-based perspective is therefore premised on the delivery of services such as water, sanitation, energy and healthcare in slum settlements.

Land administration and land tenure systems have a bearing on slum upgrading. For instance, in Zimbabwean cities, land is mainly owned by the state and municipalities. In this regard, 'the HSUP was made possible through land availed by the government' (A5). Thus, the fact that the land invaded by slum dwellers was state land, made it easy for the government to donate the piece of land for slum upgrading. In contrast, most slums in Kampala are located on privately owned land (Mugamba, 2016), due to the fact that $52 \%$ of the total land in Kampala is privately owned under the Mailo land tenure system (Giddings, 2009). Private ownership of land complicates the process of slum upgrading in the city due to lengthy negotiation processes and high costs of land compensation.

Moreover, Kampala city has multiple land administration institutions including Kampala City Council Land Board, Uganda Land Commission, and Buganda Land Board with each pursuing its own interests irrespective of the urban development standards as stipulated by the National Physical Planning Act 2010 (MLHUD, 2013a). Thus, the implementation of policies and enforcement of regulations concerning management and prevention of slum proliferation has been hindered due to the overlapping and uncoordinated institutional framework for both land administration and physical planning. In this case, 'slum upgrading requires extensive negotiations with land owners or administrators which often has a tendency to scuttle municipal or government attempts to upgrade slums' (A14).

Despite contentious political relations between the City of Harare, the ruling party and the national government, the HSUP managed to diffuse inter-party politics. This is largely because of a combination of factors that include: an apolitical mayor, the rituals of the federation which depoliticised the project, and a stable political environment brought by the inclusive government (2009-13) (Muchadenyika, 2015b). For the case of Kampala city, rent-seeking, political antagonism and the failure to defuse political tension among others have created a hostile environment for meaningful slum upgrading to take place. Therefore, we argue that inclusive city leadership and the ability to diffuse party-politics are fundamental factors in explaining the success of slum upgrading programmes.

\section{Conclusion}

Considering its anti-slum history, the City of Harare shows a different trajectory through the Harare Slum Upgrading Programme. The article has argued that such a change in approach was due to mainly 
three factors. First, the leadership of both political and administrative wings of the City of Harare played a fundamental role in accepting the reality of slums in the city and embarking on a slum upgrading programme. Second, the City of Harare developed supportive policies to facilitate slum upgrading in the city. Such policies became instrumental in guiding and supporting slum upgrading. Third, the slum upgrading alliance in Harare managed to whittle down the negative aspects of politics in slum areas through changing the target site and emphasising the apolitical nature of the upgrading project.

In Uganda, despite the presence of policies and legal frameworks at national level, these have not been adequately internalised at city level by KCCA. It can therefore be concluded that the management of slum upgrading in Kampala city has also been hindered by the absence of vital policy frameworks to guide the development of the city. The import of the discussion above is that the policy framework in its current state does not sufficiently address challenges related to slum upgrading. In such instances, slum upgrading becomes an ad hoc activity which lacks funding and not interwoven in the mainstream urban development agenda.

Basing on evidence in Harare and Uganda, the following are the critical issues for consideration in slum upgrading:

\subsection{Inclusive leadership}

City leaders tend to ignore and even disenfranchise slum dwellers. However, in African cities, informality is on a tremendous rise, meaning slums are a permanent feature in these cities. Hence, slum dwellers are vital stakeholders in city planning and governance. As such, we argue that inclusive municipal governance is fundamental in the success of slum upgrading initiatives. This is through mayors, councillors and city managers incorporating the aspirations and imaginations of slum dwellers in the planning and management of cities.

\subsection{Diffusing political tensions}

People living in slums are normally entangled in tensions associated with local and national politics. Politicians, in particular, often try to hijack and control slum upgrading processes as a way to canvass and entrench political support. In this regard, political tensions have a tendency to forestall, divert and destabilise slum upgrading. In such a context, taking an apolitical approach dilutes political tensions and associated challenges. Such an approach entails slum dwellers themselves realising the destabilising role of tensional party-politics and taking a stand against such politics in their daily collective action, organisations and interactions.

\subsection{Policy frameworks}

Most existing city policy frameworks do not normally take into cognisance slum upgrading. Hence, it becomes imperative to develop policy frameworks that guide and upscale slum upgrading. In particular, such frameworks should address issues like urban planning, infrastructure and finance which all have direct impacts to slum upgrading. In addition, a slum upgrading framework is important in guiding practical steps during slum upgrading.

\section{References}

Archer, D. (2009). Social capital and participatory slum upgrading in Bangkok, Thailand (DPhil Thesis)Cambridge: University of Cambridge, Sidney Sussex College.

Asiimwe, F. W. (2016). The role of leadership collaboration in city management: Evidence from Kampala and Kigali cities. International Journal of Technology Management, 1(1), $1-10$.

Bernard, L., Bird, J., \& Venables, A. J. (2016). The urban land market: A computable equilibrium model applied to Kampala City. Oxford: University of Oxford.

Bidandi, F., \& Williams, J. J. (2016). The challenges facing urbanisation processes in Kampala. Urban Forum, 28(2017), 235-249.

Brown, M. A. (2012). Uganda's new urban policy: Participation, poverty, and sustainability. Sustainable Futures: Architecture and urbanism in the Global South, Kampala, Uganda, 27-30 June 2012.

Brown, M. A. (2014). Uganda's emerging urban policy environment: Implications for urban food security and urban migrants. Urban Forum, 25(2), 253-264.

Bunnell, T., \& Harris, A. (2012). Reviewing informality: Perspectives from urban Asia. International Development Planning Review, 34(4), 339-347.

Butcher, C. (1995). Urban low-income housing: a case study of the Epworth Squatter Settlement Upgrading Programme. In L. M. Zinyama, D. S. Tevera, \& D. Cumming (Eds.). Harare: The growth and problems of the city (pp. 61-64). Harare: University of Zimbabwe Publications.

Chirisa, I. (2011). Inclusive cities and housing: analysis of stewardship instruments in Epworth, Zimbabwe. Paper presented at the FIG Working Week 2011: Bridging the gap between cultures. Marrakech, Morocco, 18-22 May 2011.

Cirolia, L. R., Gorgens, T., van Donk, M., Smit, W., \& Drimie, S. (2016). Upgrading informal settlements in South Africa: A partnership-based approach. Cape Town: UCT Press.

COH DHCS (2012). Department of Housing and Community Services Annual Report 2011 Harare: City of Harare.

COH DUPS (2012). Department of Urban Planning Services annual report 2011. Harare: City of Harare. .

Coit, K. (1998). Housing policy and slum upgrading in Ho-Chi-Minh City. Habitat International, 22(3), 273-280.

Das, A. (2015). Slum upgrading with community-managed microfinance: Towards progressive planning in Indonesia. Habitat International, 47(2015), 256-266.

Davis, M. (2006). Planet of slums. London: Verso.

Diacon, D. (1997). Slum networking: An innovative approach to urban development. Coalville: Building and Social Housing Foundation.

Dobson, S., Lutwama, M., \& Mugisa, F. (2014). Negotiated planning: Breaking the implementation impasse in Kampala. Paper prepared for presentation at the 'Annual World Bank Conference on Land and Poverty' The World Bank - Washington DC, April 2014.

Dudwick, N., Hull, K., Katayama, R., Shilpi, F., \& Simler, A. K. (2011). From farm to firm: Rural-urban transition in developing countries. Washington, DC: World Bank Publications.

Fontein, J. (2009). Anticipating the tsunami: Rumours, planning and the arbitrary state in Zimbabwe. Africa, 79(3), 369-398.

Giddings, S. W. (2009). The land market in Kampala, Uganda and its effects on settlement patterns. Washington, DC: International Housing Coalition.

Goodfellow, T. (2013). Planning and development regulation amid rapid urban growth: Explaining divergent trajectories in Africa. Geoforum, 48, 83-93.

GoU (1998). The land act 1998. Kampala: Uganda Printing and Publishing Corporation.

GoU (2008). National slum upgrading strategy and action plan. Kampala: Ministry of Lands, Housing and Urban Development.

GoZ (2009). Second national housing convention report. 29-30 October 2009, Elephant Hills Hotel, Victoria Falls. Harare: Ministry of National Housing and Social Amenities.

GoZ (2012). National Housing Policy 2012. Harare: Ministry of National Housing and Social Amenities.

GoZ (2013). Constitution of Zimbabwe amendment (No. 20), Act 2013. Harare: Government Printer.

Handzic, K. (2010). Is legalized land tenure necessary in slum upgrading? Learning from Rio's land tenure policies in the Favela Bairro Program. Habitat International, 34, $11-17$.

Huchzermeyer, M. (2008). Slum upgrading in Nairobi within the housing and basic services market: A housing rights concern. Journal of Asian and African Studies, 43(1), 19-39.

John Paul II Justice and Peace Centre (2011). Living in Kampala slum: A socio-economic analysis in ten informal settlements of Kampala. Kampala: John Paul II Justice and Peace Centre.

Jones, G. B. (2012). 'Bankable slums': The global politics of slum upgrading. Third World Quarterly, 33(5), 769-789.

Jones, P., Bird, J., Beck, C., \& Haas, A. (2016). Kampala: A policy narrative. Washington, DC: World Bank.

Kamete, A. Y. (2009). In the service of tyranny: Debating the role of planning in Zimbabwe's urban 'clean-up' operation. Urban Studies, 46(4), 897-922.

Kamete, A. Y. (2013). On handling urban informality in Southern Africa. Geografiska Annaler: Series B, Human Geography, 95(1), 17-31.

Karyeija, G. K., \& Kyohairwe, S. B. (2012). Organizational puzzles of agencification: A Kampala City Council Authority Case, Uganda. Journal of African and Asian Local Government Studies, 1(4), 106-115.

KCCA (2012). Kampala physical development plan. Kampala: KCCA.

KCCA (2014). Kampala strategic plan 2014/15-2018/19: Laying the foundation for Kampala City transformation. Kampala: KCCA.

Kriger, N. (2012). ZANU PF politics under Zimbabwe's "power-sharing" government. Journal of Contemporary African Studies, 30(1), 11-16.

Lall, S. V., Henderson, J. V., \& Venables, A. J. (2017). Africa's cities: Opening doors to the world. Washington, DC: World Bank.

Lambright, G. M. S. (2012). Opposition Politics and Urban Service Delivery in Kampala, Uganda. Development Policy Review. 32, s39-s60.

Leftwich, A. (2004). What is Politics: The Activity and its Study. Cambridge: Polity Press.

Lemanski, C. (2014). Augmented informality: South Africa's backyard dwellings as a byproduct of formal housing policies. Habitat International, 33, 472-484.

Lwasa, S., Nyakaana, J. B., \& Segendo, H. (2007). Population, urban development and the environment in Uganda: The case of Kampala city and its environs. A paper presented to the PRIPODE workshop on urban population, development and environment dynamics in developing countries jointly organized by CICRED, PERN and CIESIN with support from the APHRC, Nairobi. Retrieved from http://www.cicred.org/Eng/ Seminars/Details/Seminars/PDE2007/Papers/NYAKAANA_paperNairobi2007.pdf, Accessed date: 25 November 2017. 
Majale, M. (2008). Employment creation through participatory urban planning and slum upgrading: The case of Kitale, Kenya. Habitat International, 32, 270-282.

Marx, B., Stoker, T., \& Suri, T. (2013). The economics of slums in the developing world. Journal of Economic Perspectives, 27(4), 187-210.

McGregor, J. (2013). Surveillance and the city: Patronage, power-sharing and the politics of urban control in Zimbabwe. Journal of Southern African Studies, 39(4), 783-805.

Minnery, J., Argo, T., Winarso, H., Hau, D., Veneracion, C. C., \& Forbes, D. (2013). Slum upgrading and urban governance: Case studies in three South East Asian cities. Habitat International, 39, 162-169.

MLHUD (2013a). Issues paper for the development of the National Urban Policy. Kampala: Ministry of Lands, Housing and Urban Development.

MLHUD (2013b). Lands, housing and urban development sector strategic plan 2013/ 14-2017/18. Kampala: MLHUD.

MLHUD (2015). Ministry of Lands, Housing and Urban Development Statistical Abstract2015. Kampala: MLHUD.

MLHUD (2016a). Towards achieving SDG 11 in Uganda: Making cities and human settlements inclusive, liveable, safe, resilient, productive and sustainable. Kampala: MLHUD.

MLHUD (2016b). The Uganda National Housing Policy. Kampala: MLHUD.

Muchadenyika, D. (2015a). Land for housing: A political resource - reflections from Zimbabwe's urban areas. Journal of Southern African Studies, 41(6), 1219-1238.

Muchadenyika, D. (2015b). Slum upgrading and inclusive municipal governance in Harare, Zimbabwe: New perspectives for the urban poor. Habitat International, 48, $1-10$.

Muchadenyika, D. (2017). Social movements and planning institutions in urban transformation: housing in metropolitan Harare, Zimbabwe (DPhil Thesis)Cape Town: University of the Western Cape.

Muchadenyika, D., \& Williams, J. J. (2016). Social change: Urban governance and urbanization in Zimbabwe. Urban Forum, 27, 253-274.

Mugamba, U. (2016). Developing the slum main street: An urban intervention in Kisenyi, Kampala. Ottawa: Carleton University.

Mukhija, V. (2001). Upgrading housing settlements in developing countries: The impact of existing physical conditions. Cities, 18(4), 213-222.

Mukiibi, S. (2011). An evaluation of factors that have influenced housing policy development in Uganda. Proceedings of the 2nd International Conference on Advances in Engineering and Technology organized by Faculty of Technology, Makerere University. Vol. 31. Proceedings of the 2nd International Conference on Advances in Engineering and Technology organized by Faculty of Technology, Makerere University (pp. 43-49).

Mukiibi, S. (2012). The effect of urbanisation on the housing conditions of the urban poor in Kampala, Uganda. Noida: Second international conference on advances in engineering and technology. Vol. 3. Noida: Second international conference on advances in engineering and technology (pp. 37-42). . Retrieved from https://www.mak.ac.ug/documents/ Makfiles/aet2011/Mukiibi.pdf.

Musisi, J. S. (2017). More revenue collection by strengthening land administration in Kampala Uganda. Responsible land governance: towards an evidence based approach. World Bank Conference on Land and Poverty. Washington, DC: World Bank.

O'Hare, G., Abbott, D., \& Barke, M. (1998). A review of slum housing policies in Mumbai. Cities, 15(4), 269-283.

Olthuis, K., Benni, J., Eichwede, K., \& Zevenbergen, C. (2015). Slum upgrading: Assessing the importance of location and a plea for a spatial approach. Habitat International, 50, $270-288$.

Otieno, H. (2011). Community yoices in sustainable slum-upgrading processes: The Nairobi people settlement network. Nairobi: French Institute for Research in Africa65-74.

Otiso, K. F. (2003). State, voluntary and private sector partnerships for slum upgrading and basic service delivery in Nairobi City, Kenya. Cities, 20(4), 221-229.

Parikh, H., Surkar, D., \& Zanders, M. O. (2003). Sustainable infrastructure development for slums and villages. In B. Reed (Ed.). Proceedings of the 28th WEDC Conference
'Sustainable environmental sanitation and water services'. WEDC, University of Loughborough.

Parliament of Zimbabwe (2006). Second report of the Portfolio Committee on Local Government on progress made on the Operation Garikai/Hlalani Kuhle. Presented to Parliament of Zimbabwe, June 2006 (S. C. 21, 2006).

Patel, K. (2013). A successful slum upgrade in Durban: A case of formal change and informal continuity. Habitat International, 40, 211-217.

Peters, B. G. (2004). Politics is about governing. In A. Leftwich (Ed.). What is politics: The activity and its study? (pp. 23-40). Cambridge: Polity Press.

Potts, D. (2006). 'Restoring order'? Operation Murambatsvina and the urban crisis in Zimbabwe. Journal of Southern African Studies, 32(2), 273-291.

Potts, D. (2008). Displacement and livelihoods: The longer term impacts of Operation Murambatsvina. In M. Vambe (Ed.). The hidden dimensions of operation Murambatsvina in Zimbabwe (pp. 53-64). Harare \& Pretoria: Weaver Press \& Africa Institute of South Africa.

Rakodi, C. (1989). Housing production in Harare Zimbabwe: Components, constraints and policy outcomes. Trial, 20, 14-30.

Ramsamy, E. (2006). The World Bank and urban development: From projects to policy. London \& New York: Routledge.

Resnick, D. (2014). Urban governance and service delivery in African cities: The role of politics and policies. Development Policy Review, 32(S1), s3-s17.

Roy, A. (2005). Urban informality: Toward an epistemology of planning. Journal of the American Planning Association, 71(2), 147-158.

Roy, A. (2009a). Why India can plan its cities: Informality, insurgence and the idiom of urbanization. Planning Theory, 8(1), 76-87.

Roy, A. (2009b). Civic governmentality: The politics of inclusion in Beirut and Mumbai. Antipode, 41(1), 159-179.

Ssenyonga, A. (2016). KCCA to upgrade slums in Kampala. [Online]. (Accessed 159 2017).

Syagga, M. P. (2011). Land tenure in slum upgrading projects. Nairobi: French Institute for Research in Africa103-113.

Tibaijuka, K. A. (2009). Building prosperity: housing and economic development. London: Earthscan.

Tomlinson, R. (2015). Scalable community-led slum upgrading: The Indian alliance and community toilet blocks in Pune and Mumbai. Habitat International, 50, 160-168.

Tripathi, D. (1999). Slum networking in Ahmedabad: The Sanjay Nagar pilot project. London: Development planning unit.

Uganda Bureau of Statistics (2016). The National Population and Housing Census 2014 Main report. Kampala: Uganda Bureau of Statistics.

UN-Habitat (2002). Expert group meeting on slum indicators: Secure tenure, slums and global sample of cities. Nairobi: UN-Habitat.

UN-Habitat (2003). The challenge of slums: Global report on human settlements 2003. London: Earthscan.

UN-Habitat (2014). The State of African Cities: Re-imagining sustainable urban transitions. Nairobi: UN-Habitat.

UN-Habitat (2016). Urbanization and Development: Emerging Futures. World Cities Report 2016. Nairobi: UN-Habitat.

Van Ballegooijen, J., \& Rocco, R. (2013). The ideologies of informality: Informal urbanisation in the architectural and planning discourses. Third World Quarterly, 34(10), 1794-1810.

Verma, G. D. (2000). Indore's habitat improvement project: Success or failure? Habitat International, 24(1), 91-117.

World Bank (1993). Housing, enabling markets to work. Harare: World Bank.

World Bank (2015). The growth challenge: Can Ugandan cities get to work? Uganda economic update (5th Edition). Washington: World Bank.

Zimstat (2012). Census 2012: National report. Harare: Government of Zimbabwe. 